\title{
Edukacja międzykulturowa na poziomie uniwersyteckim w Polsce w kontekście nabywania nowych kompetencji przez młodzież
}

Streszczenie: W artykule zamierzam skoncentrować się na edukacji międzykulturowej jako przedmiocie akademickim w Polsce - w kontekście nabywania nowych kompetencji przez młodzież. Po pierwsze, analizie poddałam programy zajęć pod kątem oczekiwanych efektów uczenia się: wiedzy, umiejętności i kompetencji międzykulturowych, które studenci powinni zdobyć podczas kursu. Uwzględniłam zakres tematów poruszanych podczas kursu, liczbę godzin, a także formę zajęć oferowanych na uniwersyteckich kierunkach pedagogicznych w Polsce. Chciałabym również podzielić się własnymi doświadczeniami zebranymi podczas pracy ze studentami w związku z prowadzonym przeze mnie przedmiotem z zakresu edukacji międzykulturowej na wydziale pedagogicznym. W tekście przedstawię studenckie wizje edukacji międzykulturowej - na podstawie stworzonych przez nich scenariuszy zajęć dla dzieci. Moim zdaniem projekty te mogą odsłonić poziom wiedzy studentów na temat różnorodności kulturowej, kompetencje do przyszłej pracy w zróżnicowanych kulturowo środowiskach, a także ich podejście do edukacji międzykulturowej na poziomie szkolnictwa wyższego.

Słowa kluczowe: edukacja międzykulturowa, scenariusze studenckie, kompetencje międzykulturowe

Wzmożone kontakty międzygrupowe i interakcje ponadnarodowe, liczne spotkania międzykulturowe w przestrzeniach społecznych, masowe migracje wymagają od nas namysłu nad własną tożsamością kulturową i wypracowania właściwych postaw wobec innych grup, które na trwałe wpisały się w europejski krajobraz kulturowy. Ważnym jest, aby począwszy od najniższych etapów edukacji szkolnej nabywać umiejętności sprawnego funkcjonowania w środowiskach heterogenicznych kulturowo. Na każdym szczeblu edukacyjnym warto wprowadzać zajęcia na temat wielokulturowości, których efektem będzie wzmocnienie kompetencji międzykulturowych. Na kompetencje o tym charakterze składają się: 
- wiedza i stosunek do Innych (relacje z Innym);

- spostrzeganie siebie i własnej tożsamości w wielokulturowym świecie;

- znajomość i stosunek do kultury duchowej Innych (do świata idei, wartości, dorobku kultury umysłowej);

- wiedza i stosunek do kultury materialnej (i przyrody) Innych (Lewowicki, 2011, s. 34).

Potrzebna jest także w moim przekonaniu intensyfikacja kształcenia w zakresie edukacji międzykulturowej na uniwersytetach, upowszechnienie przedmiotowych zajęć w systemie akademickim. Jako nauczyciel akademicki na kierunku pedagogika spotykam się z rosnącą polaryzacją postaw studentów wobec Innego: od afirmacji różnorodności kulturowej i chęci jej poznania - poprzez obawy o zachowanie własnego dziedzictwa kulturowego (przy względnej tolerancji, szczególnie wobec potrzeb imigrantów) - do niemal całkowitego zamknięcia się na Obcego i prezentowania postaw etnocentrycznych. Zauważam jednocześnie dość powszechną nieznajomość podstawowych pojęć, kategorii i idei wielokulturowości wśród studentów. Niejednokrotnie w trakcie realizacji zajęć mam okazję zaobserwować coraz większe zainteresowanie tematyką międzykulturową, jak również autentyczne zdziwienie zróżnicowaniem kulturowym naszego kraju czy pojmowaniem inności w literaturze przedmiotu. Badania Ilony Nowakowskiej-Buryły i Marzeny Okrasy (2016, ss. 131-142) wydają się potwierdzać te spostrzeżenia. Wiedza na temat mniejszości narodowych wśród studentów pedagogiki nie jest imponująca. Badanych 148 studentów pierwszego i drugiego stopnia tego kierunku połowicznie znało pojęcie mniejszości narodowej (nikt nie udzielił w pełni poprawnej odpowiedzi), ponadto badana grupa nie potrafiła poprawnie wskazać wszystkich mniejszości narodowych oraz posiadała stosunkowo niewielką wiedzę na temat kultury, religii, tradycji poszczególnych mniejszości. Podkreślić należy, że ankietowani nie mieli w trakcie studiów wyodrębnionych zajęć z zakresu edukacji międzykulturowej. Na zaniedbania edukacji formalnej w zakresie przekazywania wiedzy o Innych wskazuje również w swych badaniach Alina Szczurek-Boruta (2013).

Tymczasem w „świecie różnicy” każdy z nas - a przede wszystkim pedagog - winien wykazać się wiedzą i otwartością na informacje o „Innych”, na dialog informacyjny, oraz zdolnością prowadzenia dialogu negocjacyjnego. Nauczyć musimy się efektywnego porozumiewania z partnerem interakcji, rozwiązywania problemów, dążyć do wzajemnego wzmacniania kulturowego (Nikitorowicz, 2013, s. 11). Należy zadbać o wielowymiarowe przygotowanie przyszłych nauczycieli: „nie tylko wyposażenie ich w wiedzę, ale także kształ- 
towanie i zmianę mentalności, budowanie wrażliwości społecznej, rozwój kompetencji międzykulturowych oraz kształtowanie postawy zaangażowania w rozwiązywanie problemów na płaszczyźnie społeczeństwa wielokulturowego" (Dąbrowska i Markowska-Manista, 2018, s. 171). Zatem nie tylko sam przekaz informacji o wielokulturowym świecie świadczyć będzie o efektywności zajęć z edukacji międzykulturowej na poziomie akademickim. Dorota Misiejuk (2013, ss. 37-38) również zwraca uwagę na kilka poziomów kompetencji niezbędnych w komunikacji międzykulturowej; jej zdaniem są to: 1) wiedza ogólna na temat odmienności kultur, uniwersalnych i specyficznych aspektów kulturowych wpływających na nasze poglądy, decyzje i zachowania; 2) emocjonalne radzenie sobie w kontaktach międzykulturowych; 3) umiejętności rozumiane jako „funkcje poprzednich poziomów i adekwatne działanie jednostki, przejawiające się w efektywnym działaniu w warunkach międzykulturowego kontaktu".

W tym kontekście warto bliżej przyjrzeć się edukacji międzykulturowej/ pedagogice międzykulturowej jako przedmiotom nauczania na poziomie akademickim. Przyczynkiem do niniejszej refleksji stały się scenariusze zajęć z edukacji międzykulturowej, które powstały w dwóch grupach studenckich: pierwsza z nich nie miała w ogóle zajęć z edukacji międzykulturowej, z kolei druga odbyła ze mną piętnastogodzinny cykl obejmujący takie zagadnienia jak: 1) podstawowa terminologia, rys historyczny, idee i programy z zakresu międzykulturowości; 2) różnice kulturowe, tożsamość kulturowa, zjawisko etnocentryzmu, stereotypy, stygmatyzacja i uprzedzenia; 3) tolerancja, dialog i komunikacja międzykulturowa; 4) wiedza o mniejszościach narodowych i etnicznych w Polsce; 5) cudzoziemcy, imigranci, uchodźcy w Polsce; 6) kompetencje pedagoga międzykulturowego, konteksty edukacji szkolnej oraz elementy metodyki. Z uwagi na fakt, iż prace studentów w obu grupach znacząco się różniły, przyjęłam, że tego typu zajęcia mogą być bardzo ważne dla nabywania kompetencji międzykulturowych, zarówno w zakresie rozwijania wiedzy, umiejętności, jak i postaw międzykulturowych studentów - przyszłych nauczycieli, pedagogów, wychowawców.

\section{Realizacja treści z zakresu edukacji międzykulturowej na poziomie akademickim w Polsce}

Przedmiot o nazwie edukacja międzykulturowa/pedagogika międzykulturowa/wczesna edukacja międzykulturowa (rzadziej: edukacja międzykulturowa w szkole, warsztaty rozwoju kompetencji międzykulturowych) wykładany 
jest obecnie na większości uniwersytetów w Polsce. Analizę jego formatu na kierunkach pedagogicznych można rozpocząć od przeglądu dostępnych sylabusów, pod kątem założonych treści kształcenia oraz oczekiwanych efektów uczenia się. Na kierunkach pedagogicznych zazwyczaj jest to kształcenie $\mathrm{w}$ formie jednego przedmiotu w semestrze, w ramach całego cyklu kształcenia Wyjątek stanowią ośrodki, w których prowadzi się zaawansowane badania nad wielokulturowością i dziedzictwem pogranicza kultur, tutaj tworzone są specjalne moduły kształcenia pedagogów międzykulturowych: pogranicze polsko-litewsko-białorusko-ukraińskie (zespół Jerzego Nikitorowicza z Uniwersytetu w Białymstoku), pogranicze polsko-czeskie na Śląsku Cieszyńskim (zespół Tadeusza Lewowickiego z Uniwersytetu Śląskiego) oraz pogranicze polsko-niemiecko-czesko-słowackie (zespół Zenona Jasińskiego z Uniwersytetu Opolskiego). Studia międzykulturowe prowadzone są również przez jednostki uniwersyteckie (wydziały, katedry, zespoły) w Bydgoszczy, Gdańsku (tutaj połączone w module wraz z edukacją regionalną), w Krakowie, Lublinie, Poznaniu, Toruniu, Warszawie i Zielonej Górze (Ogrodzka-Mazur, 2018, s. 67).

W sylabusach poddanych analizie w trakcie kursu z edukacji międzykulturowej na kierunkach pedagogicznych najczęściej poruszane są następujące zagadnienia ${ }^{1}$ :

- główne pojęcia i kategorie (międzykulturowość, wielokulturowość, transkulturowość, edukacja globalna, tożsamość kulturowa, narodowa i etniczna) oraz orientacje i modele edukacji międzykulturowej,

- aspekty polityki multiculturalizmu, procesów formowania się społeczeństw wielokulturowych, problemy i wyzwania wielokulturowości,

- programy i projekty międzykulturowe w Polsce i na świecie,

- mniejszości narodowe i etniczne w Polsce,

- tożsamość kulturowa, narodowa, etniczna, regionalna,

- stereotypy, uprzedzenia, dyskryminacja, tolerancja,

- cudzoziemcy w Polsce, imigranci, uchodźcy,

- akulturacja, komunikacja międzykulturowa, konflikty międzykulturowe, strategie radzenia sobie z różnicami kulturowymi,

- teorie pogranicza kultur,

- edukacja międzykulturowa w środowisku szkolnym.

1 Analizie poddano sylabusy na kierunkach pedagogicznych w następujących uniwersytetach: UMCS w Lublinie, UJ w Krakowie, Uniwersytet Gdański, Uniwersytet Śląski w Katowicach i Cieszynie, UKW w Bydgoszczy, UMK w Toruniu, Uniwersytet w Białymstoku, UAM w Poznaniu, Uniwersytet Warszawski, Uniwersytet Łódzki, Uniwersytet Zielonogórski, UWM w Olsztynie, Uniwersytet Opolski. 
Uczenie się międzykulturowe studentów pedagogiki rozumiane jako proces nabywania wiedzy, umiejętności i kompetencji międzykulturowych przekłada się na następujące planowane efekty kształcenia (ujednolicone na podstawie przenalizowanych sylabusów):

Tabela 1. Zestawienie głównych efektów kształcenia dla przedmiotu edukacja międzykulturowa

\begin{tabular}{|c|c|c|}
\hline Wiedza & Umiejętności & Kompetencje \\
\hline $\begin{array}{l}\text { - wiedza na temat założeń EM, } \\
\text { jej form, treści i metod stosowa- } \\
\text { nych w EM } \\
\text { - wiedza o zjawiskach wielokul- } \\
\text { turowych, międzykulturowych, } \\
\text { edukacji międzykulturowej, } \\
\text { komunikacji międzykulturowej } \\
\text { i możliwych nieporozumieniach } \\
\text { - grupy mniejszościowe } \\
\text { - potrzeby osób należących do } \\
\text { innych kręgów kulturowych } \\
\text { - wiedza o kontekście kulturo- } \\
\text { wym, więziach społecznych i pra- } \\
\text { widłowościach nimi rządzącymi } \\
\text { istotnych z punktu widzenia EM } \\
\text { - wiedza o strukturze i funk- } \\
\text { cjonowaniu systemu edukacji } \\
\text { w środowisku zróżnicowanym } \\
\text { kulturowo }\end{array}$ & $\begin{array}{l}\text { - zdolność przygotowania zajęć } \\
\text { związanych z EM } \\
\text { - umiejętność diagnozowania } \\
\text { środowiska międzykulturowego } \\
\text { - krytyczna ocena programów, } \\
\text { kampanii społecznych i projektów } \\
\text { służących EM } \\
\text { - zdolność do pracy } \\
\text { w środowisku zróżnicowanym kul- } \\
\text { turowo, twórczo animować prace } \\
\text { w środowisku heterogenicznym } \\
\text { - umiejętność opisu i wyjaśnienia } \\
\text { procesów kulturowych, zjawisk } \\
\text { społecznych w zakresie wielokul- } \\
\text { turowości } \\
\text { - umiejętność efektywnej } \\
\text { komunikacji w różnych kontek- } \\
\text { stach kulturowych (zawodowym, } \\
\text { edukacyjnym, prywatnym) }\end{array}$ & $\begin{array}{l}\text { - Student zna wartość praktycz- } \\
\text { nego działania w ramach EM } \\
\text { - współdziała w grupie, realizuje } \\
\text { zadania praktyczne z EM, jest } \\
\text { gotowy do współpracy między- } \\
\text { kulturowej } \\
\text { - jest wrażliwy na problemy } \\
\text { społeczne, tolerancyjny } \\
\text { - jest odpowiedzialny za zacho- } \\
\text { wanie dziedzictwa kulturowego } \\
\text { regionu, kraju, Europy i świata } \\
\text { - jest przygotowany do poro- } \\
\text { zumienia się z Innym, radzenia } \\
\text { sobie z nieporozumieniami } \\
\text { kulturowymi } \\
\text { - posiada zdolność krytycznej } \\
\text { refleksji dotyczącej stereotypów } \\
\text { i oceny działań pedagogicznych }\end{array}$ \\
\hline
\end{tabular}

Źródło: opracowanie własne.

Założenia dotyczące treści przedmiotu i postulowanych kompetencji, które powinien uzyskać student, są rozległe. Zważywszy na ograniczoną liczbę godzin, na wielu wydziałach mogą być trudne do zrealizowania (dominuje bowiem 30 godzin wykładu w jednym semestrze, nie zawsze rozszerzonego ćwiczeniami). Formy zaliczenia wykładu to przede wszystkim testy wiedzy lub grupowe prezentacje multimedialne. $Z$ kolei w przypadku ćwiczeń/konwersatoriów są to różne projekty działań, projekty sytuacji edukacyjnych wspierających rozwój jednostki odmiennej kulturowo, prace pisemne zawierające koncepcje edukacji międzykulturowej, projekty badawcze na temat mniejszości, diagnozy problemów obecnych w środowisku wielokulturowym czy eseje naukowe. Niekiedy warunki zaliczenia przedmiotu mają charakter łączony: test wiedzy i projekt. Wśród wielu form zaliczeń dominują jednak scenariusze zajęć dotyczące edukacji międzykulturowej.

Zadania studenckie mogą stanowić w moim przekonaniu jeden $\mathrm{z}$ istotnych wyznaczników uzyskanych kompetencji międzykulturowych, jak również pewnego rodzaju świadectwo postrzegania przez nich zjawiska wielokulturowości i procesów międzykulturowych, a zarazem są one propozycją 
„doświadczania wielokulturowości” skierowaną do przyszłych wychowanków.

\section{Scenariusze - Grupa I}

Prace studenckie kierowane były głównie do dzieci przedszkolnych i uczniów z klas I-III, zapewne z uwagi na specjalizację przedszkolną i wczesnoszkolną. Studenci nie mieli wcześniej warsztatów międzykulturowych ani zajęć na studiach z zakresu edukacji międzykulturowej. W znacznej mierze działali zatem intuicyjnie. Na zajęciach otrzymali ode mnie wykaz literatury, polecanych stron internetowych oraz godzinny wykład na temat założeń edukacji międzykulturowej wraz z informacją na temat zaliczenia w postaci scenariusza zajęć. Pracowali w grupach 2-3-osobowych, mieli miesiąc na przygotowanie pracy. W 20 scenariuszach poddanych analizie dominowało kilka tematów:

1. Kultura i styl życia w Afryce (7 projektów na temat ogólnie potraktowanego kontynentu, 1 scenariusz dotyczył struktury etnicznej Somalii);

2. Kultura i styl życia mieszkańców Chin (4);

3. Codzienność w innych kulturach (4): „Gdzie śpią dzieci”; „Każdy inny, wszyscy ważni”; „Codzienne życie i zwyczaje ludów i różnych krajów (Indie, Brazylia, Egipt, Grenlandia)”; „Tacy sami jak my, czyli codzienność w różnych kulturach";

4. Wielokulturowa Europa, wiedza o krajach UE (2);

5. Kultura wybranych krajów: Iranu (1), Maroka (1).

Formy proponowanych zajęć były ciekawe i zróżnicowane: pogadanka, pokaz, film, fotografie, zabawy ruchowe, taniec, muzyka tradycyjna, mapa, burza mózgów, mini testy wiedzy, slajdy, puzzle, bajki etniczne, prezentacja owoców egzotycznych, przedmiotów (chusta arafatka, pałeczki do jedzenia), zadania plastyczne. Wśród pomysłów na realizację zajęć pojawiły się m.in.: fotografie domów, zwierząt, roślin, strojów ludowych, flag i zadania z dopasowywaniem ubiorów, budynków, symboli narodowych, etc. Studenci proponowali dzieciom słuchanie opowiadania o historii życia chłopca z Afryki, czytanie listu od dziewczynki z Chin, słuchanie bajek afrykańskich, naukę rymowanek arabskich, przegląd fotografii z różnymi pokojami dziecięcymi (Afryka, Nowy Jork, Chiny, Nepal, Izrael, Japonia), zdjęcia z Festiwalu Róż, krótkie rozmówki w języku arabskim lub chińskim, naukę znaków chińskich, sztukę jedzenia pałeczkami, smakowanie mandarynek i daktyli. Ponadto w zajęcia wplatano zabawy ruchowe: np. muzyka ludowa, 
taniec etniczny. Uzupełniająco proponowano prace plastyczne: np. tworzenie somalijskiej grzechotki, malowanie flag europejskich, rysowanie własnej pustyni, tworzenie obrazu siebie i ważnych osób, rzeczy i miejsc, portret Przyjaciela z daleka („nadaj mu imię, napisz, co lubi robić, gdzie mieszka, gdzie chodzi do szkoły"). Ciekawą propozycją była również praca z mapą wraz z planowaniem dalekiej podróży, pakowaniem walizek, co z kolei stało się pretekstem dla spotkania z językiem i do nauki kilku zwrotów grzecznościowych przydatnych w trakcie wyprawy.

W scenariuszach znalazły się niespodziewane pomysły dydaktyczne: porównanie sypialni dzieci („czego brakuje w pokoju, który z nich jest podobny do twojego, w którym chcesz lub nie mieszkać”), jedzenie chrupek pałeczkami, fotografie tradycyjnych i nowoczesnych Chin, współczesne festiwale marokańskie. Studenci nie poprzestali na folkloryzmach grup etnicznych, lecz pokazywali również teraźniejszość i zmiany kulturowe. Skupiali się na różnicach - głównie w życiu dzieci, ich codzienności i odmiennych stylach życia, a także na przekazaniu ciekawostek kulturowych. Starali się wyeksponować pozytywne aspekty Inności (taniec, kultura materialna, jedzenie, atrakcje turystyczne). Mniej lub bardziej intencjonalnie stosowali strategię: "od wskazywania różnic do znajdowania podobieństw”, kierując się zasadą "co dzieli, a co łączy” (fotografie, rysunki, domy, szkoły, języki etc.). Rozpoczynali przeważnie od odmienności w stylu życia, potem przechodzili do jakości życia, aby ostatecznie poprzez dyskusję dotrzeć do pewnych uniwersalnych wartości. Zaskakujące, że skoncentrowali się głównie na Afryce oraz Chinach. Proponowali dzieciom zajęcia w formie krótkich, jednorazowych spotkań. Jednakże zakładane cele dydaktyczno-wychowawcze były bardzo rozległe i najczęściej należało do nich:

1) poznanie danej kultury i rozpoznanie różnic kulturowych,

2) zapoznanie z innymi warunkami życia, wzbogacenie wiedzy o różnorodności kulturowej,

3) nauka tolerancji, szacunku do inności, przekonania o konieczności poznania Innego, człowieka, wzmocnienie postaw otwartości na inne narodowości,

4) współpraca w grupie, integracja,

5) rozwój postawy twórczej, wyobraźni dziecka,

6) akceptacja samego siebie.

Studenci przedstawili w swoich projektach ogrom pomysłów wobec przewidzianych na ich realizację 45 minut lekcji. W scenariuszach dominowały różnorodne propozycje form prowadzenia zajęć. Chętnie sięgano po aspekty 
wizualne, głównie fotografie i filmy, a także mapy, atlasy, leksykony, ulotki. Nie mniej chętnie wykorzystywano fragmenty rymowanek i bajek, krótkie słowniczki zwrotów grzecznościowych. W niektórych pracach zauważyć można tendencję do ujednolicania i upraszczania danej kultury. W jednym scenariuszu zaproponowano naukę przestarzałej, nieprzystającej do rzeczywistości i powszechnie dzisiaj krytykowanej rymowanki „Murzynek Bambo w Afryce mieszka" (Kamińska, 2005, s. 62).

Po przedyskutowaniu wspólnie projektów uczestnicy zgodzili się, że jednorazowe zajęcia są niewystarczające, aby przekazać wiedzę na temat kultury chińskiej. Krytycznie odnieśli się również do potraktowania Afryki jako kultury homogenicznej. Przyznali także, że nie myśleli o zaproponowaniu lekcji problemowej, chociaż w klasach I-III można by już poruszyć temat stereotypów czy uprzedzeń. Tłumaczyli to faktem, że przygotowali scenariusze dla dzieci w wieku przedszkolnym i wczesnoszkolnym, a to w ich przekonaniu może być wiek nieadekwatny dla tego rodzaju dyskusji. Woleli tematy „pogodne", które mogłyby urozmaicić i wzbogacić lekcje, w konsekwencji skoncentrowali się na ciekawych aspektach innych kultur (zwłaszcza dotyczących sfery materialnej). Analiza projektów w tej grupie pokazała, że studenci mają wiele interesujących pomysłów, aczkolwiek nierzadko brakowało im podstaw teoretycznych ( $w$ ich przekonaniu wskazanie literatury przedmiotu jedynie w pewnym zakresie okazało się pomocne).

\section{Scenariusze - Grupa II}

W tej grupie zrealizowane projekty również kierowane były głównie do dzieci przedszkolnych i uczniów z klas I-III. I w tym przypadku studenci nie mieli wcześniej warsztatów międzykulturowych ani zajęć na studiach z zakresu edukacji międzykulturowej. Różnili się jednak od poprzedniej grupy tym, że przygotowali scenariusze po 15-godzinnym cyklu zajęć z przedmiotu o nazwie „Wczesna edukacja wielokulturowa”. Ponadto (tak jak uprzednio) otrzymali wykaz literatury, polecanych stron internetowych wraz z informacją na temat wymaganego zaliczenia w postaci scenariusza zajęć. Pracowali w grupach 2-3-osobowych, mieli miesiąc na przygotowanie pracy zaliczeniowej.

Tym razem w 20 scenariuszach poddanych analizie nie można wyróżnić wspólnych tematów. Uczestnicy kursu proponowali dzieciom poznanie kultury azjatyckiej (Chiny, Armenia, Czeczenia), afrykańskiej bądź wybranej kultury europejskiej (Włochy, Hiszpania) - aż 4 projekty dotyczyły Ukrainy, 3 - Romów w Polsce. Interesowało ich również codzienne życie w wybranych 
krajach (Kuba, Japonia, Kamerun, Meksyk), m.in. potrawy, wystrój domu, wygląd klasy szkolnej, strój codzienny i odświętny. Kilkukrotnie w scenariuszach pojawiała się problematyka tolerancji i akceptacji. Przygotowano również dwa scenariusze na temat osób niepełnosprawnych oraz kolejne trzy o uchodźcach. W jednym projekcie skupiono się na adaptacji ucznia z Hiszpanii w polskiej szkole. Punktem wyjścia była tutaj refleksja, jak dzieci czują się w nowym środowisku, w jaki sposób chciałyby być przyjęte do nowej grupy, jakie zachowania rówieśników pomogłyby im poczuć się swobodnie. Przy okazji w trakcie kilku spotkań dzieci miałyby zapoznać się z informacjami o Hiszpanii i jej kulturze.

W grupie II dotrzec można wielość metod i formy pracy, takich jak: pogadanka, burza mózgów, dyskusja, praca zbiorowa, indywidualna. Chętnie sięgano po mapy, fotografie, filmy, zabawy ruchowe i plastyczne. W kilku projektach pojawiły się zabawy „Jesteśmy do siebie podobni” i „Czy łatwo się różnić?" oraz zadania typu „ułóż narodowe puzzle”, a także gra zręcznościowa z przekazywaniem piłeczek - w której jedno z dzieci dostaje dwie piłeczki w różnych kolorach. Podaje jedną do kolegi po prawej stronie i mówi: „Jestem do ciebie podobny, bo... ”. A potem podaje drugą i mówi: „Różnię się od ciebie, bo.... Proponowano także ćwiczenia symulujące brak wzroku, niepełnosprawność rąk, leworęczność: na przykład rysowanie domu i podpisywanie się z zamkniętymi oczami, zawiązywanie kokardy przy użyciu jednej ręki, wycięcie kwadratu lewą ręką. Jedna grupa w ramach scenariusza pt. „Ciemność nie musi być straszna” przygotowała zestaw informacji, jak należy zachować się w obecności osoby niewidomej i psa przewodnika, prezentację alfabetu Braille'a oraz zadanie zapisu na kartkach swoich imion brajlem. Projekt zakładał też wizytę w toruńskim ,Niewidzialnym domu".

W grupie II także znalazły się zaskakujące pomysły dydaktyczne: zabawa w rozpoznawanie imion romskich - w której zadaniem dzieci było odnalezienie ukrytych w różnych częściach sali karteczek z imionami. Później wspólne odczytano imiona i odgadywano, czy jest to imię damskie czy męskie. Następnie każde dziecko wybierało imię romskie, które najbardziej mu się spodobało. W kolejnym projekcie zaproszono uczniów klas pierwszych do wspólnego stworzenia mapy Afryki, tańców afrykańskich, oglądania fotografii tradycyjnych strojów i tworzenia ozdób do włosów. W jeszcze innych pojawiły się na przykład propozycje pracy plastycznej „Zabytki ormiańskie w Polsce", przygotowania ukraińskiej sałatki z kiszoną kapustą i burakami, nauki czeczeńskiego tańca ludowego, czy wspólne tworzenie bajki międzykulturowej albo plakatu z okazji Światowego Dnia Uchodźców. 
Scenariusze najczęściej uwzględniały kilka elementów: przekaz wiedzy o danej kulturze, zabawy i zadania, podsumowanie - w trakcie którego starano się wywołać u dzieci refleksję. W grupie II pojawiło się więcej różnoaspektowych zdań i scenek dramowych w ramach jednego projektu zajęć. Scenariusz „Każdy z nas jest inny, ale wyjątkowy” zakładał podjęcie dyskusji na następujące kwestie społeczne:

- Do Waszej klasy dołączył nowy kolega. Jednak różni się od Was wyglądem, sposobem ubierania się, a nawet zachowaniem. Okazuje się, że pochodzi z Egiptu i jest muzułmaninem. Jego rodzice przenieśli się do Polski z powodów ekonomicznych. Staracie się pomóc Hassanowi w adaptacji do nowych warunków.

- Bierzecie udział w szkolnej wycieczce, na której znajduje się dziewczynka z niepełnosprawnością ruchową. Porusza się ona na wózku. Chcecie iść do kina, ale najbliższy budynek nie jest wyposażony w udogodnienia dla osób z niepełnosprawnościami (brak podjazdów, brak windy). $\mathrm{Mu}$ sicie podjąć jakąś decyzję.

- Julka pochodzi z mało zamożnej rodziny, ale jest bardzo dobrą i koleżeńską uczennicą. Lubicie z nią rozmawiać, pomimo krytyki pozostałych osób z klasy, którym przeszkadza, że Julka nie ma pieniędzy.

- Odgrywacie scenę, w której jedna osoba jest niewidoma. Akcja rozgrywa się nieopodal ruchliwej ulicy.

- Antek dokucza Krysi, ponieważ ta ma rude włosy i liczne piegi na nosie. W dodatku nosi okulary. Antek na jednej z przerw zabiera Krysi okulary i rozbija je. Pani nauczycielka nie widzi całej sytuacji. Jedynymi świadkami jesteście Wy.

- Kasia ma problemy z wyrażaniem własnych emocji. Mimo że cieszy się ze wspólnej zabawy, to nie potrafi tego okazać. Zastanawiacie się, w jaki sposób można inaczej porozumieć się z Kasią.

Wśród najczęstszych zakładanych celów dydaktyczno-wychowawczych w grupie II wyróżnić można:

1. Przybliżenie podobieństw i różnic między polską a wybraną kulturą, poznanie elementów kultury materialnej i duchowej mniejszości narodowej oraz elementów historii mniejszości narodowej (na przykład kuchni ormiańskiej, alfabetu ukraińskiego, różnic między religią prawosławną a katolicką). Ukazanie Polski jako kraju zamieszkałego przez wiele grup narodowych i etnicznych.

2. Uświadomienie uczniom istnienia różnych perspektyw i punktów widzenia, naturalności różnic między ludźmi. Ukazanie podobieństw 
występujących ponad wieloma różnicami. Uświadomienie, że dzięki różnicom każdy człowiek jest wyjątkowy, niepowtarzalny. Uwrażliwienie na różnorodność społeczną i na problematykę wielokulturowości.

3. Unaocznienie dzieciom, jak stosować w życiu codziennym postawę tolerancji, otwartości wobec osób z innych kultur, jak unikać stereotypów.

4. Zintegrowanie klasy: nauka współpracy w grupie, wykonywania poleceń nauczyciela, szanowania zdania innych osób, bycia gotowym do przyjęcia nowego ucznia w klasie.

W tej grupie studenci przyjmowali dydaktyczną drogę poprzez różnice kulturowe do uniwersalizacji wartości. Widać wyraźnie w scenariuszach chęć pokazania Innej kultury jako nowej, ciekawej, oryginalnej. Wydaje się także, że studenci starali się przekazać dzieciom podobne kompetencje, umiejętności i wiedzę, jaką sami otrzymali w trakcie zajęć, oczywiście ograniczając się do wyboru jednej grupy kulturowej, ale dbając przy tym zarówno o przekaz informacji o danej kulturze, budowanie umiejętności współpracy w grupie i wzmocnienie więzi grupowych oraz promowanie pozytywnych postaw wobec Innych. Grupa II - w odróżnieniu od grupy I - pokazała Innego w szerszej perspektywie, bowiem może nim być: cudzoziemiec, imigrant, uchodźca, przedstawiciel mniejszości narodowej, kultury sąsiadujące czy osoba niepełnosprawna. Te scenariusze miały na celu nie tylko dostarczenie wiedzy o kulturze odległej i egzotycznej, ale w niemal połowie z nich pojawił się „bliższy Inny": Kaszubi, Ukraińcy, Czeczeńcy. Ponadto o ile w pierwszej grupie akcent padał na przekaz wiedzy o innej kulturze, o tyle w drugiej również na modyfikację postaw, niwelowanie stereotypów, adaptację i budowanie zgodnych relacji w zróżnicowanej kulturowo grupie rówieśniczej.

W obu zespołach przeanalizowanych scenariuszy dostrzec można wielość metod i pomysłów dydaktycznych, dostosowanych do wieku dziecka. Niemniej jednak w grupie II pojawiło się więcej wątków do zrealizowania w trakcie zajęć z dziećmi. Tutaj zdecydowanie dominowały lekcje cykliczne, przewidziane przynajmniej na kilka spotkań. Jest to istotna różnica, bowiem „realizacja zajęć w postaci krótkiego, jednodniowego epizodu wycisza naturalne zainteresowanie dziecka, a brak kontynuacji podjętych tematów nie sprzyja budzeniu u niego poczucia przynależności do szerszych zbiorowości (np. własnego kraju czy Europy), utrudnia mu wchodzenie w krąg kulturowy oraz poznanie kultur innych państw" (Suchodolska, 2011, s. 17).

Uczestnicy z grupy II w trakcie spotkania podsumowującego kurs i wyznaczone zadanie akcentowali, że zajęcia zmieniły ich optykę patrzenia na wielokulturowość: 
Wcześniej w ogóle nie myślałam o wielokulturowości.

Teraz wiem, jak ważne jest zaprzyjaźnianie uczniów z „innością”.

Poznałam obyczaje niektórych kultur, o których wcześniej nie wiedziałam.

Moim zdaniem jest to ciekawe, bo pokazuje różne rodzaje inności. Nie tylko np. mniejszości narodowe, ale wszystkiego rodzaju inności, które są wokół nas. Wielokulturowość to nie tylko uchodźcy czy osoby z dalekich krajów.

To także rozwijanie wartości takich jak tolerancja, akceptacja.

Dotarło do mnie, że na każdym kroku spotykamy się z „innością” i że od najmłodszych lat warto uświadamiać o tym dzieci.

Z kolei zapytani o kryteria wyboru tematu wyjaśniali, iż kierowali się własnymi zainteresowaniami, ale także tym, aby lekcja była ciekawa dla dzieci. Zastanawiali się także, jak duże jest prawdopodobieństwo, że w przyszłej pracy zawodowej spotkają się z daną kulturą. Inną ważną przesłanką była dostrzegana przez nich dyskryminacja oraz obecna sytuacja w Polsce, podejście Polaków do Innych, a co za tym idzie, chęć niwelowania stereotypów, przezwyciężenia wśród młodych osób uprzedzeń, uwrażliwienia dzieci na akceptację drugiego człowieka. Ponadto zaobserwowali pojawienie się w polskiej szkole coraz większej liczby uczniów z innych kręgów kulturowych.

\section{Wnioski}

W studenckich scenariuszach sięgano po metody poszukiwania wiedzy o innych oraz wspólnych korzeni, a także zrozumienia i poszanowania odmienności, budowania współpracy. W grupie II pojawiły się dodatkowo metody pracy ze stereotypami, w mniejszym zakresie strategie rozwiązywania problemów (por. Sielatycki, 2004).

Projekty przybierały wiele form, łączyło je skoncentrowanie na dostarczaniu informacji o wybranych kulturach i zróżnicowaniu kulturowym oraz podkreślanie podobnych elementów i uniwersalnych wartości pomiędzy grupami narodowymi i kulturami (por. Weigl, 2020). Charakterystyczne, że tylko w jednym scenariuszu studenci zaproponowali zorganizowanie spotkania z członkami innej grupy narodowej.

W obu grupach studenckich ujawniły się wysokie kompetencje metodyczne, nadal jednak konieczne jest podnoszenie kompetencji merytorycznych w zakresie międzykulturowości. Jak starałam się pokazać, już 15 godzin zajęć znacząco wpływa na jakość merytoryczną projektów. Studenci z dwóch zespo- 
łów pomijali złożoność kwestii dotyczących kontaktów z Innymi, co po części można jednak wytłumaczyć wiekiem potencjalnej grupy odbiorców propozycji dydaktycznych. Wydaje się również, że skoncentrowali się bardziej na wielokulturowości, w mniejszym zaś stopniu na potencjale międzykulturowości (zwłaszcza grupa pierwsza). Ponadto w projektach zabrakło odniesień do aktualnej sytuacji globalnych migracji, i tak na przykład w żadnym scenariuszu na temat Chin nie uwzględniono faktu, iż wielu Chińczyków mieszka i pracuje obecnie w Polsce. Innymi słowy, nie wykorzystano okazji, aby podkreślić, że daleki obcy jest teraz wśród nas. Nie zawsze udawało się wykroczyć poza folkloryzm danej grupy, co może podtrzymywać mylne wrażenie o statyczności tejże kultury (przykładem są scenariusze na temat nomadyzmu Romów).

Mariola Badowska (2018, s. 197) odnotowuje: „Na wielu uczelniach przygotowujących do zawodu nauczycieli i pedagogów kształcenie i doskonalenie przyszłych pracowników szkoły w zakresie kompetencji społecznych, a zwłaszcza w zakresie kompetencji międzykulturowych, wciąż nie stanowi priorytetu". Te słowa oraz doświadczenie lektury scenariuszy obu grup pozwalają mi wysunąć postulat, aby studenci kierunków pedagogicznych mieli możliwość odbycia zajęć z edukacji międzykulturowej, przynajmniej w wymiarze 15 godzin, w formie konwersatorium (optymalnie 30 godzin wykładu i dodatkowo konwersatorium/warsztaty). Programy kursów w świetle przestudiowanych sylabusów są wyczerpujące, można jednak pokusić się o ich wzbogacenie, tak aby zawierały dwa komponenty: wiedzę merytoryczną oraz trening postaw wobec Inności (Korczyński, Świdzińska, 2017, s. 126). Scenariusze zajęć stanowią niezwykle korzystną formę zaliczenia, ze względu na możliwość poznania sposobów rozumienia zjawisk kulturowych z perspektywy studentów, jak również potencjał współpracy grupowej studentów. Ważne jest, by zajęcia kończyły się krytyczną analizą wykonanych konspektów, co dodatkowo wzmocni umiejętność oceny projektów dotyczących międzykulturowości.

Bardzo potrzebne są również dalsze badania na temat rzeczywistej wiedzy studentów o zjawiskach i procesach wielokulturowych, ich rozumienia Inności i postrzegania edukacji międzykulturowej, w tym tego, w jaki sposób wyobrażają sobie ten przedmiot na uniwersytecie. Czy cechuje ich ciekawość poznawcza, chęć uczenia się i poznawania kultur, czerpania wiedzy ze spotkań międzykulturowych? (por. Paszenda, 2013). Postawy przyszłych pedagogów wobec nabywanie wiedzy o innych kulturach i nastawienie do zdobywania/rozwijania kompetencji do pracy w zróżnicowanych kulturowo środowiskach należy potraktować priorytetowo. 


\section{Bibliografia}

Badowska, M. 2018. Kompetencje społeczne i międzykulturowe nauczycieli i pedagogów w świetle badań własnych. Kultura i Edukacja. 3 (121), ss. 184-200 .

Dąbrowska, E. i Markowska-Manista, U. 2018. Przygotowanie nauczycieli i pedagogów w zakresie edukacji międzykulturowej - prezentacja projektu badawczego. Edukacja Międzykulturowa. 1, ss. 169-184.

Kamińska, K. 2013. W stronę wielokulturowości w edukacji przedszkolnej. Warszawa: PWN.

Korczyński, M. i Świdzińska, A. 2017. Wrażliwość międzykulturowa studentów z pogranicza polsko-ukraińskiego. Edukacja Międzykulturowa. 1, ss. 113$-129$.

Lewowicki, T. 2011. Cztery spojrzenia na wielokulturowość i edukację międzykulturową. Pogranicze. Studia Społeczne. 17, ss. 28-38.

Misiejuk, D. 2013. Kompetencje do komunikacji międzykulturowej w świetle procesów samooceny w warunkach historycznego zróżnicowania regionu i procesów migracyjnych - komunikat z badań. Pogranicze. Studia Spoteczne. XXI, ss. 37-44.

Nikitorowicz, J. 2013. Kompetencje do komunikacji międzykulturowej w aspekcie tradycyjnej wielokulturowości regionu i procesów migracyjnych. Wprowadzenie w realizowaną problematykę. W: Sobecki, M., Danilewicz, W., Muszyńska, J., Misiejuk, D. i Bajkowski, T. red. Kompetencje do edukacji międzykulturowej w aspekcie wielokulturowości regionu i procesów migracyjnych. Warszawa: Wydawnictwo Akademickie „Żak”, ss. 4-12.

Nowakowska-Buryła, I. i Okrasa, M. 2016. Wiedza i stosunek do mniejszości narodowych jako element kompetencji międzykulturowej studentów. Edukacja Międzykulturowa. 5, ss. 131-142.

Ogrodzka-Mazur, E. 2018. Intercultural education in Poland: current problems and research orientations. Kultura i Edukacja. 2 (120), ss. 65-82.

Paszenda, I. 2013. Kształcenie kompetencji międzykulturowych w szkole wyższej - dylematy teorii i praktyki. W: Szerląg, A. red. Wielokulturowość - międzykulturowość w edukacji akademickiej. Wrocław: Oficyna Wydawnicza ATUT, ss. 51-59.

Sielatycki, M. 2004. Metody nauczania w edukacji międzykulturowej. www.ore.edu.pl (4.06.2020), ss. 30-35.

Suchodolska, J. 2011. Wprowadzenie. W: Lewowicki, T. i Suchodolska, J. red. Dzieci w procesie ksztattowania postaw kulturowych. Przewodnik po ścieżkach edukacji regionalnej, wielo-, i międzykulturowej (materiały dla 
nauczycieli gimnazjów i szkót ponadgimnazjalnych). Katowice - Cieszyn

- Warszawa - Kraków: Oficyna Wydawnicza „Impuls”, ss. 13-19.

Szczurek-Boruta, A. 2013. Doświadczenia spoteczne w przygotowaniu przyszłych nauczycieli do pracy w warunkach wielokulturowości. Toruń: Wydawnictwo Adam Marszałek.

Weigl, B. 2020. Dylematy edukacji wielokulturowej dziecka przedszkolnego, http://miedzykulturowa.org.pl/czytelnia/artykuly/dylematy-edukacji-wielokulturowej-dziecka-przedszkolnego/ (4.06.2020)

\title{
Intercultural education at the university level in Poland in the context of acquiring new competences by youth
}

\begin{abstract}
In the paper I intend to focus on intercultural education as an academic subject in Poland in the context of acquiring new competences by young people. Firstly, the syllabus of classes will be a subject to analysis in terms of their expected learning outcomes: the knowledge, skills and intercultural competencies to be acquired by students during the course. The considered aspects will include the scope of subjects addressed during the course, the number of hours, as well as the forms of study that offer this type of higher education in Poland. I would also like to share my own experiences collected while working with students on subjects associated with intercultural education, which I have been teaching at a pedagogical faculty. Among other things, I will present their visions of what intercultural education means to them - based on their own scenarios of classes for children. In my opinion, the projects can show the level of student's knowledge on cultural diversity, their competencies related to future work in culturally diverse environments and their approach to intercultural education at the level of higher education.
\end{abstract}

Keywords: intercultural education, student scenarios, intercultural competences

Translated by Joanna Cukras-Stelągowska 